\title{
The Emergence of COVID-19 in India: A Loco-Regional, Community Perspective and Its Management
}

\author{
Abhishekh Basavarajegowda, Channaveerappa Bammigatti, \\ Srikanth Umakanthan, Shashidhar Binnamangala
}

\begin{abstract}
COVID-19 initially emerged from Wuhan, Central China in late December 2019. Its neighbouring country, India reported its first COVID-19 positive case in late January followed by a rapid surge in cases due to community spread, regional congregation meetings and presence of active super spreaders. Active surveillance was the main method for COVID-19 prevention and was strictly implemented by the Government. RT-PCR was the main investigation tool conducted by ICMR linked laboratories across the nation. Nationwide lockdown, genetic variation of virus and humid weather has shown to play vital role in epidemic spread and reduced mortality of COVID-19. Management is multipronged based on mild, moderate and severity of clinical features. Mild cases are observed for vitals, moderate cases are treated with oxygenation and steroids. Severe and critically ill patients are mainly supported by ventilators.
\end{abstract}

Index Terms - COVID-19, transmission, surveillance, investigation, supportive care.

\section{INTRODUCTION}

The first positive case of COVID-19 in India was detected in Thrissur, Kerala state in the southern part of India on January $30^{\text {th }}$ of 2020 . The patient was a medical student who returned from Wuhan[1].Over the next month, only few cases were detected and comprised of Italian tourists and their contacts[2]. This was followed by a rapid surge in the number of cases in the month of March supported by a community event which took place in Delhi during early March named "Tablighi Jamaat Congregation". This event traced to detection of over 600 cases in 14 different states in a span of two days[3]. Then it steeply increased from there on roughly adding on average 500-700 cases per day accounting to total 30000 cases by April end[4]. The first COVID related death was reported on March $11^{\text {th }} .100^{\text {th }}$ death was reported on April $6^{\text {th }}$ and $100^{\text {th }}$ death by April $29^{\text {th }}$.

Abhishekh Basavarajegowda,Department of Transfusion Medicine, Jawaharlal Institute of Postgraduate Medical Education and Research, Puducherry, India

Channaveerappa Bammigatti, Department of Medicine, Jawaharlal Institute of Postgraduate Medical Education and Research, Puducherry, India

Srikanth Umakanthan, Department of ParaclinicalSciences, Faculty of Medical Sciences, The University of the WestIndies, Mount Hope,Trinidad, and Tobago

Shashidhar Binnamangala, Consultant Intensivist, Vikram Hospitals, Bangalore, India

\section{A. Loco-Regional and Community Emergence}

The two most severely affected states in India were Maharashtra and Tamil Nadu. The initial spread and detection of COVID19 was mostly prevalent in Urban areas across the country. Koyambedu market in Chennai, proclaimed as one of the Asia's largest wholesale markets for perishable goods turned out to be one of theinitial epicentres for spread of COVID 19. This market attracts 1-2 lakhs visitors every day[5]. Dharavi, one of the largest slums (area $2.1 \mathrm{sq} . \mathrm{km}$ ) in Asia is the most densely populated areas in the world with a population density of $277,136 / \mathrm{km} 2$. In less than 45 days it recorded 1,028 cases and 40 deaths. The doubling rate was approximately 6 days and majority of infected people were in the age group of 31-40yrs[6].Dense population, lack of proper hygiene and sanitation were the most common reasons for failure of containment in these zones.Super spreaders were identified in Ahmedabad, state capital of Gujarat. It accounted for 7,044 positive cases and 473 deaths as of May 15th. "Super spreaders" are carriers of infection who could infect a large number of people who come in their contact. They consisted mostly of vegetable vendors, grocery and milk shop owners, petrol pump attendants and garbage collectors. At least a 700 of such spreaders were been identified and tested positive[7].

The exponential rise started from late May onwards almost doubling every fortnight. As of mid-August, there are6,76,900 active cases. Total number deaths reported are 50,921(1.92\%). 19,19,842 (72.51\%) have been either cured/discharged. On an average India reports about 70,000 new cases a day[8].The transmission in India is mostly local contact spread (stage 2) and community transmission (stage 3 ) in few areas[9].The case fatality rate was around $2-3 \%$. Only about $3 \%$ of the active COVID-19 patients were in ICU of which less than $15 \%$ were on ventilator support and others were on oxygen support.[8] Integrated disease surveillance program(IDSP) reported that $60 \%$ of the COVID patients had at least one comorbidity and $78 \%$ of them were under 50 years of age. Most of the patients reported to be affected are from Urban areas with less than $20 \%$ of them from rural areas[10].

India mandated a three-pronged strategy to reduce the transmission of infection which included Social distancing, hand wash and usage of face masks in public [11]. The distancing of one meter was advocated in all public. Face masks were advised for public use. Handwashing with soap water and sanitizers were encouraged while entering public 
shops. People were encouraged to reduce the usage of lifts. Other etiquettes like drastic reduction of occupants in public vehicles, maintaining distancing in the lift, elbow press/toothpicks and non-contact commands for switch and buttons of the lift were advised to the public. Schools, colleges, and universities were closed.

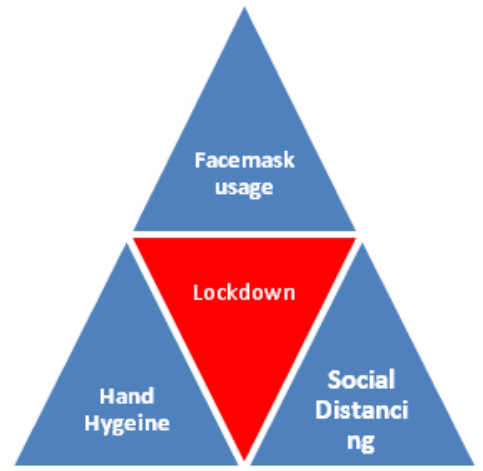

Aarogya setu: India started a digital contact tracing technology by the name "Aarogya setu" literally translating to as "bridge to health". It is a mobile application which needs to be voluntarily downloaded by people on to their mobile. The government made it mandatory for government employees to use it. It was designed to track an individual regarding his travel and to enable his/her contact history by using digital networking. By registering personal details of the user, it assigns the category as: low risk, high risk, positive, or negative and tracks them and alerts when they come near another user. It is known to be having more than hundred million users as of date[12].It is known to have alerted 1.4 lakh users as of day. Maharashtra also used drones to monitor physical distancing during lockdown[13].

\section{B. Large Scale Testing Methods}

Individuals requiringcost free testing were based on the eligibility criteria determined by the national/state policy. The testing has been carried out by the (Indian Council for Medical Research) ICMR linked/affiliated laboratories throughout the country, Government laboratories under the arm of CSIR,DBT,DRDO, Government medical colleges and nationally accredited private laboratories by RT-PCR method for throat swabs. Initially the tests were offered only to symptomatic patients and the quarantined contacts/travel history patients who had symptoms. Also, a sentinel surveillance to detect community transmission of infection was started in mid-February in designated areas. The various inclusion criteria for testing using RT-PCR have been summarized in Table.1 along with their date of implementation. Pooling of up to 5 samples for RT-PCR for testing was allowed in areas where positivity was less than $2 \%$ as per available data. Pooling was also allowed in centres where positivity rate was between $2-5 \%$ for testing on asymptomatic individuals only (excluding the samples of known contacts with positive cases and health care workers who were in direct contact with COVID-19 patients). As of date India has performed close to 30 million tests at close to 1400 testing centres (941 in public and 465 in private sectors). Highest number of centres in Uttar Pradesh, Maharashtra, and Tamil Nadu around 150 centres each. The testing rate is about 22 per 1000 populations (2.2\%) and the positivity rate is around $8 \%$. Few laboratories also use
Cartridge Based Nucleic Acid Amplification Test (CBNAAT) using Cepheid Xpert Xpress SARS-CoV2[14].

A rapid antibody-based blood test was initiated in early April 2020 for areas reporting clusters cases and large migration gathering/evacuees. COVID-19 positive cases were referred to hospitals whereas COVID-19 negative cases were home quarantined. The tests were repeated on COVID-19 negative patients at the end of 10 days and were then exempted from home quarantine. The various testing methods used are summarised in Table 2.

A screening test "TrueNat" was approved to be used as a screening test for Covid 19 testing. It is a Taqman chemistry chip based real time PCR testing; A point of care testing technology prevalently being used for Tuberculosis testing. However for confirmation RTPCR was mandated subsequently for the TrueNat positive cases[15].

Government implemented containment measures and other most noticeable features of COVID-19 in India

Active surveillance is the principle method practised in India for COVID-19 containment. Passive reporting is comparatively low as the regular OPDs and elective surgeries are disrupted with only emergency services functioning in most of the hospitals and health care facilities [16].

Two types of quarantine are in practice in India for suspects and contacts -Home and Institutional. The home quarantine was implied for cases with 14 days contact with a confirmed case or earlier if the suspect case with which he/she was in contact, tests negative. This was applied only if a well-ventilated single room was available preferably with an attached toilet. Family was restricted to meet these individuals. Other quarantine locations were government designated facilities such as hotels, hostels, and school buildings. If the quarantined individual turned positive they were immediately transferred to a hospital facility for either treatment or quarantine based on symptoms[17].

India was projected to have $250,000,000$ totals (asymptomatic, symptomatic and hospitalized) infections, $2,500,000$ cases requiring hospitalization and 1,000,000 needing ventilators with peaking of cases towards the end of April and beginning of May 2020[18].As on 13th May 2020, India had less than 50,000 confirmed cases and 2415 deaths[8].We shall envision the reasons for slower increase in cases and lesser mortality in India.

Lockdown: Nationwide lockdown for 21 days was announced by Honourable Prime Minister on 24th of March 2020. Doubling rate of COVID 19 cases before lockdown was 3 days, which increased to 6.2 days after about 3 weeks of lockdown. Average growth factor of cases was 2.1 between 15th and 31st March which fell to 1.2 from April 1st onwards. This was $40 \%$ reduction in increase of cases. By this time close to 2000 COVID 19 hospitals with 1.73 lakh isolation beds and 21800 ICU beds were also made ready[19]. Initial lockdown was followed by lockdown 2.0 with conditional relaxation from 15th April to 3rd May and lockdown 3.0 from 4th to 17th May according to the zones based on number of cases and doubling rate of the cases. Doubling time gradually increased to 8.5, 10.9 and 12.2 days by 13th of May 2020[20]. So, timely lockdown has probably helped in reducing the increase in number of cases significantly. 
Population demographics: As on 13th May, 294,155 deaths have been attributed to COVID 19 worldwide[21]. Older age is one of the strongest risk factors for death due to COVID 19[22],[23],[24]. Eighty percent patients who died due to COVID 19 in China by 5th February 2020 were over the age of 60 years[25]. In India, people who are more than 65 years of age constitute only $6 \%$ of the total population as compared to $23 \%$ in Italy, $20 \%, 19 \%$ in Spain, $18 \%$ in United Kingdom (UK) and $16 \%$ in United States (US) [26]. Number of deaths per million population due to COVID 19 in India is 2 as compared to 514, 580, 489 and 257 in Italy, Spain, UK and US respectively[27]. Therefore, it is possible that death rates much lower in India as compared to the many western countries.

Weather: There is some evidence that virus causing COVID 19 is temperature and humidity sensitive. The rapid spread of COVID 19 outbreak in many countries suggests that the virus has preference for cooler and drier weather[28]. Results from a scientific data model indicate that there was a negative correlation in the predicted number of cases with temperatures from $1{ }^{\circ} \mathrm{C}$ and above. An increase in the average temperature from 1 to $9{ }^{\circ} \mathrm{C}$ was associated with a decrease in predicted cases from 24 to 19 . Similarly, an increase in the average temperature from 10 to $19{ }^{\circ} \mathrm{C}$ was associated with a decrease from 18 to 7 cases[29]. In India, average summer temperature ranges from 32 to $40^{\circ} \mathrm{C}$ and humidity ranges from 50 to $70 \%$ [30]. This might explain the lower rate of increase in COVID 19 cases as compared to the temperate countries.

Genetic variations in the virus: A new strain of the COVID 19 virus was discovered by scientists that appear to be more contagious than the original one[31]. This strain appeared in Europe in February and migrated quickly to the US. Apart from being more contagious, this new strain can cause reinfections due to mutation in the spike protein. Though this new strain is spreading across the globe its spread in Asia was slower as compared to Europe and North America. This might have led to fewer cases in Asian countries such as India as compared to other European and North American countries.

BCG vaccination: India follows universal childhood BCG vaccination policy to protection against tuberculosis. BCG vaccination has been shown to protect against multiple viral pathogens like respiratory syncytial virus, Influenza A virus and Herpes simplex virus which is mediated by epigenetic reprogramming of monocytes which leads to better innate immune response[32]. The same mechanisms are thought be protecting against COVID 19 virus leading to fewer cases and lesser mortality in countries with widespread BCG vaccination.

Other factors which may be contributing to the lesser number of cases and lower mortality rate in India could be due to variations in ACE2 expression and polymorphisms in HLA genes [33][34].

Population density: India is 2nd most populous country in the world with a population density of 455 people/km2 as compared with UK's 275, Italy's 205, Spain's 94 and the US's 3625. Social distancing becomes difficult in such a populous country especially in big cities with overcrowded slums, markets, trains, buses, and offices. This might enhance the transmission of infection easily [35].
Hygienic practices: With large proportion of Indian population being below poverty line, hygienic practices such as cough etiquettes and hand hygiene are not existent. It is estimated that about 16 crore Indian population do not have access to clean water to wash their hands[36]. This may make it impossible for large proportion of population to carry out simple preventive measures such as hand hygiene to prevent COVID 19 which may increase the spread of infection.

Surveillance: Though World Health Organization (WHO) declared COVID 19 as a Public Health Emergency of International Concern on 30 January 2020, India screened only $19 \%$ of inbound international passengers between 15 th January and 23rd March 202027[37]. This would have allowed many individuals with COVID 19 infection to spread in the country. India's testing rates were the lowest among countries reporting more than 50,000 cases with 1549 tests per million population[27]. Up to $80 \%$ of COVID 19 infections are asymptomatic and detecting and isolating individuals with asymptomatic infection is an important measure to prevent spread of infection. With very low testing rates it is impossible to detect asymptomatic cases and this might lead to increase in number of COVID 19 infections in India.

\section{MANAGEMENT}

For the management of patients with COVID-19, Government of India released guidelines which are regularly updated. The patients are usually classified into Mild, Moderate and Severe (ARDS/Sepsis) based on presentation and clinical parameters. Clinical parameters utilised were fever, cough, respiratory distress, $\mathrm{SpO}_{2}$, Chest X-ray and other modalities if required and are available. Except for the mild cases who were allowed for home isolation if fulfilling few requisites (adequate facility, availability of a caregiver etc), rest all were managed in a designated Covid Healthcare facility. Mild cases were monitored with daily temperature checks, vitals and $\mathrm{O}_{2}$ saturation, deterioration of symptoms if any etc and symptomatic treatment with antipyretics, adequate nutrition and rehydration [38],[39]. Hydroxychloroquine (HCQ) under strict medical supervision was considered for patients with high risk features for severe disease such as age> 60; Hypertension, diabetes, chronic lung/kidney/ liver disease, Cerebrovascular disease, and obesity.

Moderate cases were managed by oxygen support, consideredfor steroids (either methyl prednisone or dexamethasone, Hydroxychloroquine, and anticoagulation by heparin. Empirical antibiotics were used as per local antibiogram and policy especially in older people, immune-compromised patients, and children $<5$ years of age

Severe cases were managed usually in critical care or High dependency units with High flow nasal cannula, non-invasive or invasive ventilation as required. Prone ventilation was encouraged and adapted by centres as per expertise, training, and logistics. Extra corporeal life support was utilised in available centres. Sepsis was managed by fluid resuscitation and vasopressors as required.

Investigational therapies Remdesivir, Tocilizumab, Lopinavir/Ritonavir were used in some desperate measures under caution.

Convalescent plasma collected from donors recovered 
from Covid Infection was allowed on compassionate grounds in few states for patients with moderate to severe disease. The dose used was $400-500 \mathrm{ml}$ in split doses. one vast multicentred Randomized Control study (The PLACID Trial) is initiated by Indian Council for Medical Research (ICMR) to evaluate the safety and efficacy of convalescent plasma in Covid-19 treatment and the results would be available by the end of August 2020. Government of Maharashtra announced the launch of a large trial and therapy "PLATINA Trial" in June end whereas another trial has been started by CSIR (Council of Scientific and Industrial Research) in West Bengal[40][41].

In association with Bharath Biotech International Limited, ICMR also launched a clinical trial of indigenous vaccine (BBV152 COVID) in first week of July[42].Alternative medicines from natural products of Indian origin like Curcumin and terpenoids, ayurvedic and other formulations have been tried for their potential utility to mitigate Table 1. Timeline of testing strategies adapted in India
Corona.Kabasura Kudineer, Withania Somniferous (Ashwagandha) and variety of phytochemicals have been used as possible preventive and therapeutic agents[43].

\section{CONCLUSION}

COVID-19 has been a huge barrier in terms of health and economic management in India. The lessons learnt globally over this period of COVID-19 pandemic have been actively implemented across India, yet it has left a widespread serious effect on health and economy across the nation. The Government has tried several measures in managing active spread in few states but has been severely threatened in metropolitan cities due to active migration of poor daily wage workers. The final impact of COVID-19 in the subcontinent is mainly dependable on government measures, health care infrastructure and the vital role provided by COVID-19 warriors.

\begin{tabular}{|c|c|c|}
\hline Version & Date & Strategy - RT PCR testing[14] \\
\hline I/II & $\begin{array}{c}15^{\text {th }} \text { February } \\
\& 17^{\text {th }} \text { march }\end{array}$ & $\begin{array}{c}\text { Symptomatic patients with } \\
\text { - foreign travel history up to } 14 \text { days (or) contacts of laboratory confirmed cases (or) } \\
\text { health care workers }\end{array}$ \\
\hline III & $20^{\text {th }}$ march & $\begin{array}{c}\text { All in version I/II plus asymptomatic direct and high-risk contacts of a confirmed case } \\
\text { to be tested once between day } 5 \text { and day } 14 \text { of coming in his/her contact) }\end{array}$ \\
\hline IV & $9^{\text {th }}$ April & $\begin{array}{c}\text { All in version III plus cases with severe acute respiratory Illness and Influenza like } \\
\text { illness (within } 7 \text { days of illness) }\end{array}$ \\
\hline V & $20^{\text {th }}$ April & $\begin{array}{c}\text { All Pregnant women residing in clusters/containment area or in large migration } \\
\text { gatherings/evacuees Centre from hotspot areas (as notified) and presenting in labor or } \\
\text { likely to deliver in next } 5 \text { days }\end{array}$ \\
\hline VI & $1^{\text {th }}$ May & $\begin{array}{c}\text { All hospitalized patients who develop ILI symptoms } \\
\text { All symptomatic ILI among returnees and migrants within } 7 \text { days ofIllness } \\
\text { Asymptomatic direct and high-risk contacts of a confirmed case to be tested once } \\
\text { between day } 5 \text { and day } 10 \text { of coming into contact. }\end{array}$ \\
\hline & $\begin{array}{c}\text { Recommended rapid Antigen point of Care testing in containment zones with testing } \\
\text { of symptomatic patients by RTPCR }\end{array}$ \\
\hline
\end{tabular}

Table 2. Testing methods used for COVID-19 in India

\begin{tabular}{|c|c|}
\hline Method & Utility \\
\hline Real time RT-PCR & Designated virology laboratories \\
\hline TrueNat and CBNAAT & District hospitals and Primary health care levels \\
\hline $\begin{array}{l}\text { Rapid Antigen detection } \\
\text { test }\end{array}$ & At field, tracing positives. Negatives if symptomatic should be retested by PCR \\
\hline $\begin{array}{l}\text { IgG Antibody test for } \\
\text { COVID-19 }\end{array}$ & $\begin{array}{l}\text { For surveillance of population exposed to infection including asymptomatic } \\
\text { individuals, high risk or vulnerable populations and identifying potential convalescent } \\
\text { plasma donors }\end{array}$ \\
\hline
\end{tabular}

\section{REFERENCES}

[1] Varghese GM JR. COVID-19 in India: Moving from containment to mitigation. Indian J Med Res 2020; 151: 136-139.

[2] Singhal T. A Review of Coronavirus Disease-2019 (COVID-19). Indian J Pediatr 2020; 87: 281-286.

[3] Ramesh S. The four stages of Covid-19 transmission \& why India maintains it is not yet in stage 3. The print, https://theprint.in/health/the-four-stages-of-covid-19-transmission-wh y-india-maintains-it-is-not-yet-in-stage-3/395349/ (2020, accessed 30 June 2020).

[4] India - daily cumulative COVID-19 tests 2020 | Statista, https://www.statista.com/statistics/1113465/india-coronavirus-covid-1 9-tests-cumulative/ (accessed 30 June 2020).
[5] Lakshmi K SJ. Coronavirus | How panic buying at Chennai's Koyambedu market created a COVID-19 cluster. The Hindu, https://www.thehindu.com/news/cities/chennai/coronavirus-how-panic -buying-at-chennais-koyambedu-market-created-a-covid-19-cluster/art icle31595931.ece (accessed 30 June 2020).

[6] Dharavi's journey to becoming Mumbai's Covid-19 hotspot. Times of India,

https://timesofindia.indiatimes.com/city/mumbai/dharavis-journey-tobecoming-mumbais-covid-19-hotspot/articleshow/75737056.cms (accessed 30 June 2020).

[7] Ahmedabad: 700 'super spreaders' found coronavirus positive in a week. The Economic Times, https://economictimes.indiatimes.com/news/politics-and-nation/ahmed abad-700-super-spreaders-found-coronavirus-positive-in-a-week/articl eshow/75780194.cms?from=mdr (accessed 30 June 2020). 
[8] \#IndiaFightsCorona COVID-19 in India, Corona Virus Tracker mygov.in, https://www.mygov.in/covid-19/ (accessed 30 June 2020).

[9] SP B. Coronavirus | India's COVID-19 doubling time slows to 13.9 days. The Hindu, https://www.thehindu.com/news/national/coronavirus-26235-personshave-been-cured-so-far-says-health-ministry/article31585089.ece (accessed 30 June 2020).

[10] Home:: Integrated Disease Surveillance Programme(IDSP), https://idsp.nic.in/ (accessed 6 July 2020).

[11] Garg S, Bhatnagar N, Gangadharan N. A Case for Participatory Disease Surveillance of the COVID-19 Pandemic in India. JMIR Public Heal Surveill 2020; 6: e18795.

[12] Surveillance in the Time of Coronavirus: The Case of the Indian contact tracing Aarogya Setu, https://data-activism.net/2020/04/bigdatasur-covid-surveillance-in-the -time-of-coronavirus-the-case-of-the-indian-contact-tracing-app-aarog ya-setu/ (accessed 30 June 2020).

[13] The Lancet. India under COVID-19 lockdown. Lancet 2020; 395: 1315.

[14] Testing Strategy, https://www.icmr.gov.in/cteststrat.html (accessed 30 June 2020).

[15] Time CR, Test PCR, Coronavirus B, et al. Truenat ${ }^{\mathrm{TM}}$ Beta CoV, http://www.molbiodiagnostics.com/product_details.php?id=54.

[16] K V. With efficient, speedy and action-oriented contact tracing, we can be step ahead of the virus. Int Cent Theor Sci Newsl 2020; VI: 1-3.

[17] Government of India Ministry of Health \& Family Welfare Revised guidelines for Home Isolation of very mild/pre-symptomatic COVID-19 https://www.mohfw.gov.in/pdf/Guidelinesforhomequarantine.pdf, (accessed 30 June 2020).

[18] Klein E, Tseng K, Schueller E, et al. COVID-19 for India Updates. 2020.

[19] Doubling rate of Covid-19 cases in India reduced after lockdown, says Health Ministry. The Print, https://theprint.in/india/doubling-rate-of-covid-19-cases-in-india-redu ced-after-lockdown-says-health-ministry/403993/ (accessed 30 June 2020).

[20] Coronavirus cases doubling time slows down to 12.2 days from 10.9 . Times of

India, https://timesofindia.indiatimes.com/india/coronavirus-cases-doublingtime-slows-down-to-12-2-days-from-10-9/articleshow/75706726.cms (accessed 30 June 2020).

[21] COVID-19 Map - Johns Hopkins Coronavirus Resource Center, https://coronavirus.jhu.edu/map.html (accessed 30 June 2020).

[22] Wang K, Zuo P, Liu Y, et al. Clinical and laboratory predictors of in-hospital mortality in patients with COVID-19: a cohort study in Wuhan, China.

[23] Zangrillo A, Beretta L, Scandroglio AM, Montag, Kominsky E CS et al. Characteristics, Treatment, Outcomes, and Cause of Death of Invasively Ventilated Patients With COVID-19 ARDS PracticeUpdate,

https://www.practiceupdate.com/content/characteristics-treatment-out comes-and-cause-of-death-of-invasively-ventilated-patients-with-covi d-19-ards/100111 (2020, accessed 30 June 2020).

[24] Mehra MR, Desai SS, Kuy S, et al. Cardiovascular Disease, Drug Therapy, and Mortality in Covid-19. N Engl J Med. Epub ahead of print 1 May 2020. DOI: 10.1056/nejmoa2007621.

[25] Coronavirus: Window of opportunity to act, World Health Organization says. BBC News, https://www.bbc.com/news/world-asia-china-51368873 (accessed 30 June 2020).

[26] Population ages 65 and above (\% of total population). The world Bank, https://data.worldbank.org/indicator/SP.POP.65UP.TO.ZS (accessed 30 June 2020).

[27] Coronavirus Update (Live): Worldometer, https://www.worldometers.info/coronavirus/ (accessed 30 June 2020).

[28] Will warm weather really kill off Covid-19? BBC Future, https://www.bbc.com/future/article/20200323-coronavirus-will-hot-w eather-kill-covid-19 (accessed 30 June 2020).

[29] Bannister-Tyrrell M, Meyer A, Faverjon C, et al. Preliminary evidence that higher temperatures are associated with lower incidence of COVID-19, for cases reported globally up to 29th February 2020 medrxiv. Epub ahead of print 2020. DOI 10.1101/2020.03.18.20036731.

[30] Seasonal Forecast, https://mausam.imd.gov.in/imd_latest/contents/seasonal_forecast.php\# . India Meteorological Department (accessed 30 June 2020).
[31] Korber B, Fischer W, Gnanakaran SG, et al. Spike mutation pipeline reveals the emergence of a more transmissible form of SARS-CoV-2. bioRxiv 2020; 2020.04.29.069054.

[32] O'Neill LAJ, Netea MG. BCG-induced trained immunity: can it offer protection against COVID-19? Nature Reviews Immunology 2020; 20 : 335-337.

[33] Cao Y, Li L, Feng Z, et al. Comparative genetic analysis of the novel coronavirus (2019-nCoV/SARS-CoV-2) receptor ACE2 in different populations. Cell Discov 2020; 6: 11.

[34] Nguyen A, David JK, Maden SK, et al. Human leukocyte antigen susceptibility map for SARS-CoV-2. J Virol; 94. Epub ahead of print 17 April 2020. DOI: 10.1128/jvi.00510-20.

[35] Population density (people per sq. $\mathrm{km}$ of land area) | Data, https://data.worldbank.org/indicator/EN.POP.DNST (accessed 30 June 2020).

[36] Sheikh S. Lack of Clean Water for India's Poor Spawns Virus Concerns - $\quad$ The Diplomat, https://thediplomat.com/2020/03/lack-of-clean-water-for-indias-poor-s pawns-virus-concerns/ (accessed 30 June 2020).

[37] Dasgupta S. India screened only $19 \%$ of inbound passengers for Covid until 23 March, RTI reply reveals. The print, https://theprint.in/health/india-screened-only-19-of-inbound-passenger s-for-covid-until-23-march-rti-reply-reveals/422140/ (accessed 30 June 2020).

[38] Ministry of Health and Family Welfare. CLINICAL MANAGEMENT PROTOCOL : COVID-19. Version 4 https://www.mohfw.gov.in/pdf/ClinicalManagementProtocolforCOVI D19.pdf (2020).

[39] Umakanthan S, Sahu P, Ranade A V, et al. Origin , transmission , diagnosis and management of coronavirus disease 2019 ( COVID-19). Postgr Med J 2020; 1-6.

[40] Fight against COVID-19 Project Platina - world's largest convalescen plasma therapy project launched in Maharashtra India News, https://www.timesnownews.com/india/article/project-platina-worlds-1 argest-convalescent-plasma-therapy-project-launched-in-maharashtra/ 613842 (accessed 30 June 2020).

[41] Search Result,Clinical Trials Registry - India (CTRI), http://ctri.nic.in/Clinicaltrials/advsearch.php (accessed 29 June 2020).

[42] Press release https://main.icmr.nic.in/sites/default/files/press_realease_files/ICMR_ Press_Release_04072020.pdf (accessed 6 July 2020).

[43] Shetty R, Ghosh A, Honavar S, et al. Therapeutic opportunities to manage COVID-19/SARS-CoV-2 infection: Present and future. Indian J Ophthalmol 2020; 68: 693.

Dr.Abhishekh Basavarajegowda MBBS, MD, DNB, MNAMS, PGDCR Associate Professor in Transfusion Medicine, JIPMER.

Principal Investigator of ICMR-PLACID Trial. Atleast 25 publications in reputed Journals. i-10 index 2

Dr. Channaveerappa Bammigatti MBBS,MD ,Additional Professor in Medicine, JIPMER. Faculty of 450 bedded COVID 19 designated hospital.

Dr. Srikanth Umakanthan MBBS,MD Department of ParaclinicalSciences, Pathology Unit, Faculty of Medical Sciences, The University of the WestIndies Publication: Umakanthan S,Sahu P, Ranade $\mathrm{AV}$, et al.Postgrad Med J Epub aheadof print: doi:10.1136/postgradmedj-2020-138234

Dr. Shashidhar BinnamangalaMBBS,MD, FNB(Critical care) Is a consultant Intensivist in Vikram Hospitals, Bengaluru which is hospital treating large number of Covid patients 